\title{
PENGARUH PIJAT AROMATERAPI LAVENDER TERHADAP TINGKAT NYERI PERSALINAN KALA I FASE AKTIF
}

\author{
Finta Isti Kundarti, Ira Titisari, Naning Tri Windarti
}

\begin{abstract}
Pain in the labor are predisposition for anxiety, hyperventilation, thus causing oxygen requirements and increased blood pressure. Pain in the labor can be reduced by nonpharmacological methods, one of which is using aromatherapy. Lavender as an aromatherapy effect relaxation, pain relief, reduces anxiety and causes calmness. The purpose of this research was to know the effect of lavender massage aromatherapy to the level of the first stage of labor pain in the active phase of first stage labor. The research design used quasi experiment with pre-test post-test with control group design. The population in this research that the whole maternal active phase of the first stage in BPM Blabak's Community Health Center Kediri Regency. The research time is June $23^{\text {th }} 2014$ until July $19^{\text {th }} 2014$. Total samples in this research is 20 respondents with consecutive sampling techniques. The research instrument used scale observation. Statistical tests in this study using the paired $t$ test.The results showed $t$ value $(11,000)>t$ table $(2,262)$ and $P$ value $(0.000)<\alpha(0.05)$, then $\mathrm{H} 0$ is rejected, which means there is effect of lavender (Lavandula angustifolia) massage aromatherapy to the pain labor level of the active phase in the first stage of labor. So the conclusion of lavender massage aromatherapy down the level of pain in the active phase of the first stage of labor. This method can be applied midwives to help reduce pain during childbirth.
\end{abstract}

Keywords: Lavender Aromatherapy, Pain, Labor, Massage

\section{PENDAHULUAN}

Persalinan merupakan proses fisiologis yang terjadi pada setiap wanita. Persalinan merupakan suatu proses pengeluaran hasil konsepsi (janin, air ketuban, selaput plasenta dan plasenta) keluar kandungan melalui jalan lahir. Persalinan dikatakan normal apabila presentasi janin belakang kepala, tidak mempunyai komplikasi-komplikasi lain dan dapat lahir dengan tanpa bantuan serta lamanya persalinan tidak melebihi 24 jam (Hakimi, 2010).

Salah satu tanda mulainya persalinan yaitu adanya kekuatan his yang makin sering terjadi dan dengan jarak semakin pendek. Nyeri persalinan kala I merupakan proses yang fisiologis. Nyeri persalinan kala I disebabkan oleh adanya dilatasi serviks, hipoksia pada sel-sel otot uterus yang memendek (effacement), serta adanya tekanan pada struktur sekitar. Adanya his atau kontraksi uterus menyebabkan pembuluh-pembuluh saraf dan pembuluh darah tertekan. Tekanan pada pembuluh saraf akan menyebabkan rasa sakit atau nyeri.

Nyeri persalinan dapat menimbulkan kecemasan pada pasien, menyebabkan timbulnya hiperventilasi sehingga kebutuhan oksigen dan tekanan darah meningkat. Keadaan ini akan merangsang peningkatan katekolamin yang dapat menyebabkan gangguan pada kontraksi uterus sehingga terjadi inersia uteri yang mengakibatkan persalinan menjadi lama (Subekti, 2004).

Berdasarkan SDKI 2012, penyebab kematian ibu terbesar yaitu perdarahan (42\%), eklampsi/ preeklampsi (13\%), abortus (11\%), infeksi (10\%), partus lama/ persalinan macet (9\%), dan penyebab lain 
(15\%). Sedangkan di Jawa Timur, penyebab kematian terbesar ibu karena pre eklampsia $(34,88 \%)$, perdarahan $(25,09 \%)$, jantung $(8,08 \%)$, infeksi $(4,98 \%)$ dan lain-lain (26,98\%). Kota kediri, angka kejadian partus lama tahun 2012 sebanyak 26 kasus dan pada tahun 2013 sebanyak 24 kasus (Dinas Kesehatan Kota Kediri, 2014). Sedangkan data di Kabupaten Kediri pada tahun 2012 kasus persalinan lama sebanyak 378 kasus dan pada tahun 2013 ada 347 kasus. Jumlah persalinan oleh nakes di Kabupaten Kediri pada tahun 2013 di Puskesmas Blabak sejumlah 1097 kasus atau sekitar 94,16\% (Dinas Kesehatan Kabupaten Kediri, 2013).

Nyeri persalinan bisa dikurangi dengan metode non farmakologis, yaitu dengan menggunakan teknik relaksasi dan pernafasan, effleurage dan tekanan sacrum, hidroterapi, Transcutaneous Electrical Nerve Stimulation (TENS), dan teknik lain seperti hipnoterapi, masase, acupressure, aromaterapi, yoga dan sentuhan terapeutik (Scherch, 1991 dikutip oleh Bobak, 2005). Sedangkan untuk manajemen non farmakologi yang sering diberikan antara lain yaitu dengan hidroterapi, terapi masase, aromaterapi, dan tehnik behavioral yang meliputi meditasi, latihan autogenik, serta imajinasi terbimbing dan nafas ritmik (Yuliatun, 2008).

Pijat aromaterapi merupakan perawatan yang paling banyak dikenal karena minyak esensial dalam larutan aromaterapi mampu menembus kulit dan terserap ke dalam tubuh, sehingga memberikan pengaruh penyembuhan dan menguntungkan pada berbagai jaringan dan organ internal (Koensoermardiyah, 2009). Pijat aromaterapi adalah jenis pengobatan yang populer dan umum di masyarakat, bahkan paten-paten dan produk yang berkaitan dengan pijat dan aromaterapi atau gabungan keduanya telah beredar di masyarakat dan terbukti membawa efek positif sesuai tujuan penggunaannya (Sundari, 2011).
Secara fisiologis, pijatan merangsang dan mengatur tubuh, memperbaiki aliran darah dan kelenjer getah bening, sehingga oksigen, zat makanan, dan sisa makanan dibawa secara efektif ke dan dari jaringan tubuh dan plasenta. Dengan mengendurkan ketegangan dan membantu menurunkan emosi pijat juga merelaksasi dan menenangkan saraf, serta membantu menurunkan tekanan darah. Bila seseorang sedang merasa tidak sehat, pijatan dapat meningkatkan kemampuan diri untuk menyembuhkan diri sendiri dan cara ini dapat digunakan untuk melengkapi terapi alami.

Pada ibu menjelang persalinan, pijat aromaterapi dengan cara lembut dapat membantu ibu merasa lebih segar, rileks dan nyaman menjelang persalinan. Sebuah penelitian menyebutkan, ibu yang dipijat 20 menit setiap jam selama tahapan persalinan akan lebih bebas dari rasa sakit. Hal itu terjadi karena pijat merangsang tubuh melepaskan senyawa endorphin yang merupakan pereda rasa sakit alami. Endorphin juga dapat menciptakan perasaan nyaman dan enak. Banyak bagian tubuh ibu bersalin dapat dipijat, yaitu pada bagian kaki, punggung, bahu, tangan (Danuatmaja, 2008).

Berdasarkan penelitian di Amerika Serikat, 70 sampai 80 persen wanita mengalami nyeri pada saat persalinan. Sehingga di Rumah Sakit swasta banyak melakukan persalinan secara seksio sesarea sebesar 20 sampai dengan 50 persen. Peningkatan persalinan secara seksio sesarea ini dikarenakan kebanyakan ibu bersalin tidak mau merasakan nyeri pada saat persalinan. Di Brazil, angka ini mencapai lebih dari 50 persen dari angka kelahiran di rumah sakit yang merupakan persentase tertinggi di seluruh dunia (Satrioaji, 2006).

Penelitian yang dilakukan oleh Dina Indrati Dyah Sulistyowati pada 54 ibu bersalin primipara di Rumah Sakit Margono Soekarjo dan klinik bersalin di Purwokerto dengan penelitian yang melibatkan kelompok eksperimen dan 
kelompok kontrol. Penelitian tersebut menyebutkan bahwa aromaterapi lavender efektif dapat digunakan untuk mengatasi nyeri dan cemas persalinan primipara kala I (Sulistyowati, 2012).

Penelitian lain yang dilakukan pada 10 pasien bedah mayor di Rumah Sakit Dustira Cimahi menyatakan bahwa aromaterapi (aroma) lavender berpengaruh dalam penurunan intensitas nyeri, yaitu rerata intensitas nyeri sebelum diberikan aromaterapi lavender adalah 4,80 dengan standar deviasi 2,530 pada ibu sebelum pemberian aromaterapi aroma lavender menjadi 4,10 dengan standar deviasi 2,807 setelah pemberian aromaterapi aroma lavender. Jadi terdapat perbedaan signifikan rata-rata sebelum dan sesudah pemberian aromaterapi aroma lavender (Bangun, 2013).

Berdasarkan latar belakang diatas, maka peneliti tertarik untuk melakukan penelitian dengan judul "Pengaruh Pijat Aromaterapi Lavender (Lavandula Angustifolia) Terhadap Tingkat Nyeri Persalinan Kala I Fase Aktif (Studi Analitik di BPM Wilayah Kerja Puskesmas Blabak Kabupaten Kediri)".

\section{BAHAN DAN METODE PENELITIAN}

Desain penelitian ini menggunakan rancangan penelitian eksperimen semu (quasi eksperiment) dengan pre test post test design with control group, yang mengungkapkan hubungan sebab akibat dengan melibatkan kelompok kontrol disamping kelompok eksperimen. Populasi dalam penelitian ini adalah seluruh ibu bersalin primigravida kala I fase aktif di BPM wilayah kerja Puskesmas Blabak Kabupaten Kediri sebanyak 14 BPM. Teknik sampling dalam penelitian ini adalah consecutive sampling. Tempat penelitian yang digunakan adalah di BPM wilayah kerja Puskesmas Blabak Kabupaten Kediri. Waktu pengumpulan data dilakukan pada tanggal 23 Juni - 19 Juli 2014. Penelitian ini menggunakan instrumen kuesioner data umum dan skala observasi perilaku FLACC (Face, Legs, Activity, Cry, Consolability) untuk menilai tingkat nyeri. Analisa data dilakukan dengan menggunakan uji paired t test.

\section{HASIL PENELITIAN}

Dibawah ini diuraikan hasil penelitian tentang pengaruh pijat aroamterapi lavender (Lavandula angustifolia) terhadap tingkat nyeri persalinan kala I fase aktif di BPM wilayah kerja Puskesmas Blabak Kabupaten Kediri dengan jumlah responden 20 sesuai kriteria sampel.

\begin{tabular}{|c|c|c|c|}
\hline Tabel & 1. D & tribusi & Frekuensi \\
\hline No. & Usia & Frekuensi & $\begin{array}{c}\text { Persentase } \\
(\%)\end{array}$ \\
\hline 1. & $<20$ tahun & 4 & $20 \%$ \\
\hline 2. & 20-35 tahun & 15 & $75 \%$ \\
\hline 3. & $>35$ tahun & 1 & $5 \%$ \\
\hline Total & & 20 & $100 \%$ \\
\hline
\end{tabular}

Berdasar tabel 1. dapat diketahui bahwa dari 20 orang responden, lebih dari setengah responden berusia 20-35 tahun berjumlah 15 responden $(75 \%)$.

\begin{tabular}{|c|c|c|c|}
\hline \multirow[t]{4}{*}{ Tabel } & \multicolumn{2}{|c|}{$2 \quad$ Distribusi } & Frekuensi \\
\hline & \multicolumn{3}{|c|}{ Pendidikan Responden di } \\
\hline & BPM & Wilayah & Kerja \\
\hline & \multicolumn{3}{|c|}{ Puskesmas Blabak. } \\
\hline No. & Pendidikan & Frekuensi & $\begin{array}{c}\text { Persentase } \\
(\%)\end{array}$ \\
\hline 1. & Tidak sekolah & 0 & $0 \%$ \\
\hline 2. & SD & 6 & $30 \%$ \\
\hline 3. & SMP & 8 & $40 \%$ \\
\hline 4. & SMA & 5 & $25 \%$ \\
\hline 5. & Perguruan & 1 & $5 \%$ \\
\hline & Tinggi & & \\
\hline Total & & 20 & $100 \%$ \\
\hline
\end{tabular}

Berdasarkan tabel 2 diketahui bahwa hampir setengah responden memiliki tingkat pendidikan SMP yaitu sebanyak 8 responden $(40 \%)$.

\section{Tabel 3 Distribusi Frekuensi Pekerjaan Responden di BPM Wilayah Kerja Puskesmas Blabak.}

\begin{tabular}{clcc}
\hline No. & Pekerjaan & Frekuensi & Persentase(\%) \\
\hline 1. & IRT & 17 & $85 \%$ \\
2. & Swasta & 2 & $10 \%$ \\
\hline
\end{tabular}




\begin{tabular}{cccc}
\hline 3. & Wiraswata & 1 & $5 \%$ \\
4. & PNS & 0 & $0 \%$ \\
\hline & Total & $\mathbf{2 0}$ & $\mathbf{1 0 0 \%}$ \\
\hline
\end{tabular}

Berdasar tabel 3 diketahui sebagian besar responden sebagai ibu rumah tangga (IRT) yaitu sebanyak 17 responden $(85 \%)$.

Tabel 4 Data Distribusi Responden Berdasarkan Intensitas Nyeri Persalinan Kala I Fase Aktif Pada Kelompok Kontrol

\begin{tabular}{cccccccc} 
& & \multicolumn{2}{c}{$\begin{array}{c}\text { Fase } \\
\text { No }\end{array}$} & $\begin{array}{c}\text { Tingkat } \\
\text { nyeri }\end{array}$ & \multicolumn{2}{c}{$\begin{array}{c}\text { Fase dilatasi } \\
\text { akselerasi }\end{array}$} & \multicolumn{2}{c}{$\begin{array}{c}\text { Fase } \\
\text { maksimal }\end{array}$} & \multicolumn{2}{c}{ deselerasi } \\
\cline { 3 - 8 } & $\begin{array}{c}\text { Pre } \\
\text { test }\end{array}$ & $\begin{array}{c}\text { Post } \\
\text { test }\end{array}$ & $\begin{array}{c}\text { Pre } \\
\text { test }\end{array}$ & $\begin{array}{c}\text { Post } \\
\text { test }\end{array}$ & $\begin{array}{c}\text { Pre } \\
\text { test }\end{array}$ & $\begin{array}{c}\text { Post } \\
\text { test }\end{array}$ \\
\hline 1. & $\begin{array}{l}\text { Nyeri } \\
\text { ringan }\end{array}$ & 1 & 0 & 0 & 0 & 0 & 0 \\
2. & $\begin{array}{l}\text { Nyeri } \\
\text { sedang }\end{array}$ & 9 & 8 & 7 & 2 & 0 & 0 \\
3. & $\begin{array}{l}\text { Nyeri } \\
\text { sangat }\end{array}$ & 0 & 2 & 3 & 8 & 10 & 9 \\
4. & $\begin{array}{l}\text { hebat } \\
\text { Nyeri } \\
\text { terhebat }\end{array}$ & 0 & 0 & 0 & 0 & 0 & 1 \\
\hline
\end{tabular}

Berdasar tabel 4 diketahui nilai awal pre test, lebih dari setengah responden mengalami nyeri sedang dan pada post test, lebih dari setengah responden mengalami nyeri sangat hebat.

Tabel 5 Data Distribusi Responden Berdasarkan Intensitas Nyeri Persalinan Kala I Fase Aktif Pada Kelompok Eksperimen

\begin{tabular}{cccccccc}
\hline & & \multicolumn{2}{c}{$\begin{array}{c}\text { Fase } \\
\text { No }\end{array}$} & $\begin{array}{c}\text { Tingkat } \\
\text { nyeri }\end{array}$ & \multicolumn{2}{c}{$\begin{array}{c}\text { Fase dilatasi } \\
\text { akselerasi }\end{array}$} & \multicolumn{2}{c}{$\begin{array}{c}\text { Fase } \\
\text { maksimal }\end{array}$} & \multicolumn{2}{c}{ deselerasi } \\
\cline { 2 - 7 } & $\begin{array}{c}\text { Pre } \\
\text { Test }\end{array}$ & $\begin{array}{c}\text { Post } \\
\text { Test }\end{array}$ & $\begin{array}{c}\text { Pre } \\
\text { test }\end{array}$ & $\begin{array}{c}\text { Post } \\
\text { test }\end{array}$ & $\begin{array}{c}\text { Pre } \\
\text { test }\end{array}$ & $\begin{array}{c}\text { Post } \\
\text { test }\end{array}$ \\
\hline 1. & $\begin{array}{l}\text { Nyeri } \\
\text { ringan }\end{array}$ & 2 & 5 & 0 & 5 & 0 & 0 \\
2. & $\begin{array}{l}\text { Nyeri } \\
\text { sedang }\end{array}$ & 5 & 5 & 10 & 5 & 1 & 9 \\
3. & $\begin{array}{l}\text { Nyeri } \\
\text { sangat } \\
\text { hebat }\end{array}$ & 0 & 0 & 0 & 0 & 9 & 1 \\
\hline
\end{tabular}

Berdasar tabel 5 diketahui tingkat nyeri persalinan sebelum diberikan pijat aromaterapi lavender, lebih dari setengah responden mengalami nyeri sedang dan setelah diberikan pijat aromaterapi lavender, lebih dari setengah responden tetap mengalami nyeri sedang.
Hasil uji statistik pada fase akselerasi didapatkan perbedaan yang signifikan karena nilai t hitung 4.993 dengan nilai $P$ value 0,001 . Oleh karena nilai $P$ value $0,001<\alpha(0,05)$ dan nilai t hitung (4.993) $>$ nilai t tabel (2.262) maka $\mathrm{H} 0$ ditolak dan H1 diterima. Pada fase dilatasi maksimal, didapatkan nilai $\mathrm{t}$ hitung $(7.216)>$ nilai $\mathrm{t}$ tabel (2.262) dan nilai $P$ value $0,000<\alpha$ $(0,05)$ maka H0 ditolak dan H1 diterima. Sedangkan pada fase deselerasi didapatkan nilai t hitung $(11.000)>$ nilai $\mathrm{t}$ tabel (2.262) dan nilai $P$ value $0,000<\alpha$ $(0,05)$, maka H0 ditolak dan $\mathrm{H} 1$ diterima. Jadi dapat disimpulkan bahwa ada pengaruh pijat aromaterapi lavender (Lavandula angustifolia) terhadap tingkat nyeri persalinan kala I fase aktif.

\section{Pembahasan}

1. Tingkat Nyeri Persalinan Kala I Fase Aktif yang Tidak Diberi Perlakuan Pijat Aromaterapi Lavender (Lavandula angustifolia)

Hasil penelitian terhadap 10 orang responden pada kelompok kontrol pre test fase akselerasi, didapatkan bahwa 1 orang responden mengalami nyeri ringan, 9 orang mengalami nyeri sedang dan pada post test didapatkan 8 orang responden mengalami nyeri sedang dan 2 orang mengalami nyeri sangat hebat. Pada pre test fase aktif dilatasi maksimal, terdapat 7 orang responden mengalami nyeri sedang dan 3 orang responden mengalami nyeri sangat hebat, dan pada post test, 2 orang responden mengalami nyeri sedang dan 8 orang responden mengalami nyeri sangat hebat.

Sedangkan pada pre test fase aktif deselerasi, semua responden mengalami nyeri sangat hebat dan pada post test, ada 1 orang yang mengalami nyeri terhebat. Rata-rata nyeri yang dirasakan pada kelompok yang tidak diberikan pijat aromaterapi lavender yaitu mengalami nyeri sangat hebat. 
Nyeri persalinan berasal dari kontraksi miometrium dan merupakan proses fisiologis dengan intensitas berbeda-beda pada masing-masing individu (Cunningham,2004). Rasa nyeri dapat dipengaruhi oleh paritas, usia, kecemasan, dukungan keluarga, budaya dan lingkungan serta pengalaman persalinan sebelumnya (Judha, 2012).

Sejumlah 10 responden yang menjadi kelompok kontrol, pada fase deselerasi didapatkan hasil bahwa tingkat nyeri yang dialami berada pada kategori nyeri sangat hebat sejumlah 1 responden yang berusia $<20$ tahun dan 8 responden berusia 20-35 tahun. Sedangkan 1 orang responden berada pada kategori nyeri terhebat berusia > 35 tahun. Rata-rata responden yang tidak diberikan pijat aromaterapi lavender memiliki kisaran usia 20-35 tahun yang terlampir pada lampiran 7 .

Faktor usia dapat memengaruhi respon nyeri seseorang. Anak memiliki respon nyeri yang lebih tinggi bila dibanding dengan usia remaja, dewasa dan orang tua. Hal ini karena anak dapat mengekspresikan nyeri lebih bebas sedangkan pada remaja respon nyeri lebih rendah karena dapat mengontrol perilakunya, sedangkan pada usia dewasa dan orang tua lebih rendah karena menganggap nyeri merupakan proses alamiah (Maslikhanah, 2011).

Ibu yang berusia $>35$ tahun memiliki tingkat nyeri yang semakin besar bila dibanding dengan usia $<35$ tahun. Ibu yang lebih tua mempunyai metabolisme yang lebih lambat bila dibandingkan dengan ibu yang berusia lebih muda, sehingga tingkat nyeri yang dirasakan juga akan berbeda.

Selain itu, ibu yang mengalami stres dan cemas selama proses persalinan dapat menyebabkan kontraksi uterus menjadi semakin nyeri. Ibu yang sedang melahirkan dalam keadaan rileks dan nyaman tidak merasakan adanya nyeri yang sangat. Dengan begitu persalinan akan berjalan lebih mudah dan nyaman.
Faktor lain yang dapat memengaruhi nyeri yaitu dukungan dari keluarga terutama suami juga sangat membantu ibu untuk mengatasi rasa nyeri. Ibu bersalin yang ditemani atau diperhatikan oleh suami maupun keluarga dari awal proses persalinannya merasa lebih tenang dan tidak cemas akan persalinannya. Ketika ada keluarga yang memberi dukungan secara moril, ibu juga akan semakin tenang sehingga nyeri yang dirasakan akan semakin berkurang.

Faktor pendidikan juga berperan terhadap cara mengekspresikan diri terhadap nyeri persalinan. Seseorang yang berpendidikan tinggi lebih bisa memahami tentang persepsi terhadap nyeri sehingga nyeri yang dirasakan tidak sama dengan nyeri yang dirasakan pada ibu dengan tingkat nyeri dibawahnya. Seperti responden penelitian ini, pada fase deselerasi, responden yang berpendidikan SMA lebih bisa mengendalikan nyeri yang dirasakan bila dibanding dengan responden yang berpendidikan SMP, yaitu responden yang berpendidikan SMA tidak mengalami kenaikan nyeri dan tetap berada pada tingkat nyeri sangat hebat sedangkan pada responden yang berpendidikan SMP, ada 1 responden yang mengalami kenaikan tingkat nyeri dari nyeri sangat hebat menjadi nyeri terhebat.

2. Tingkat Nyeri Persalinan Kala I Fase Aktif yang Diberi Perlakuan Pijat Aromaterapi Lavender (Lavandula angustifolia)

Berdasarkan penelitian yang telah dilakukan pada 10 responden kelompok eksperimen, diberikan pre test kemudian dilakukan pemijatan dengan menggunakan aromaterapi lavender selama 20 menit. Setelah itu diberikan post test untuk mendapatkan skor skala nyeri. Pada fase aktif akselerasi, didapatkan hasil sebelum diberikan perlakuan, 2 orang mengalami nyeri ringan, 8 orang mengalami nyeri sedang dan setelah diberikan perlakuan, 5 orang 
menjadi nyeri ringan dan 5 orang mengalami nyeri sedang.

Pada fase aktif dilatasi maksimal, didapatkan hasil bahwa sebelum diberikan perlakuan 10 responden mengalami nyeri sedang dan setelah diberikan perlakuan, 5 responden mengalami nyeri ringan dan 5 orang responden mengalami nyeri sedang. Sedangkan pada fase aktif deselerasi didapatkan hasil bahwa 1 orang mengalami nyeri sedang dan 9 orang mengalami nyeri sangat hebat pada skor nyeri sebelum diberi perlakuan, dan sesudah diberi perlakuan, 9 orang responden mengalami nyeri sedang dan 1 orang responden mengalami nyeri sangat hebat. Rata-rata responden pada kelompok yang diberikan pijat aromaterapi lavender yaitu mengalami nyeri sedang.

Nyeri persalinan disebabkan oleh pasokan oksigen ke otot rahim berkurang, karena adanya kontraksi yang singkat menyebabkan nyeri menjadi lebih tinggi sehingga pasokan oksigen ke otot rahim belum sepenuhnya pulih. Seperti teori yang dikemukakan oleh Yuliatun (2008) bahwa pada kala I persalinan, nyeri disebabkan oleh adanya kontraksi uterus yang mengakibatkan dilatasi dan penipisan seviks dan iskemia pada uterus. Nyeri tersebut dirasakan ibu saat kontraksi dan menurun atau menghilang pada interval kontraksi.

Pada penelitian ini, respondennya adalah ibu bersalin primigravida. Intensitas nyeri persalinan primigravida sering kali lebih berat dari pada nyeri persalinan pada multigravida. Hal itu karena multigravida mengalami effacement bersamaan dengan dilatasi serviks, sedangkan pada primigravida, proses effacement biasanya terjadi lebih dahulu daripada dilatasi serviks. Proses ini menyebabkan intensitas kontraksi uterus yang dirasakan primipara lebih berat daripada multipara, terutama pada kala I persalinan.

Selain itu, multigravida telah mempunyai pengalaman nyeri sebelumnya sehingga multigravida telah mempunyai mekanisme untuk mengatasi nyeri persalinannya. Selain faktor paritas, faktor usia ibu juga sangat memengaruhi tingkat nyeri yang dirasakan. Semakin muda atau usia $<16$ tahun dan semakin tua usia ibu > 35 tahun, nyeri yang dirasakan juga akan semakin meningkat seiring dengan adanya faktor resiko yang terjadi pada waktu persalinannya seperti pada penilaian skor Poedji Rochyati.

Pada penelitian ini, ada satu responden yang memiliki usia 36 tahun, pada pembukaan 9-10 cm nyeri yang dirasakan mencapai nilai tertinggi yaitu nyeri terhebat. Jadi pada ibu usia > 35 tahun, nyeri yang dirasakan akan semakin meningkat dibandingkan nyeri yang dirasakan pada ibu yang memiliki usia lebih muda atau $<35$ tahun.

Penggunaan teknik pengurangan rasa nyeri persalinan dapat dilakukan dengan metode nonfarmakologis seperti relaksasi, teknik pernafasan, perubahan posisi, massage, aromaterapi, hidroterapi, musik serta metode-metode lain yang dapat diterapkan. Aromaterapi adalah terapi komplementer dengan menggunakan minyak esensial yang diambil dari bau harum tumbuh-tumbuhan. Aromaterapi dapat diberikan dengan cara penghirupan, pengompresan, pengolesan dikulit, perendaman dan akan lebih efektif disertai pijatan (Bakir, 2009).

Penggunaan aromaterapi dalam persalinan membantu ibu untuk menurunkan tingkat nyeri. Salah satu minyak aromaterapi yang bisa digunakan untuk mengurangi nyeri yaitu lavender. Minyak esensial lavender memiliki kandungan perelaksasi, antispasmodik dan pereda nyeri. Oleh sebab itu, lavender berguna untuk meredakan nyeri kontraksi terutama pada saat persalinan (Praptiani, 2012).

Pijat menggunakan aromaterapi lavender ini dapat menurunkan nyeri yang diasakan melalui mekanisme sistem penciuman. Dimana bau yang dihasilkan ditangkap oleh olfactory ephitelium, yang merupakan suatu reseptor yang berisi 20 
juta ujung syaraf. Selanjutnya, bau tersebut akan ditransmisikan sebagai suatu pesan ke pusat penciuman yang terletak pada bagian belakang hidung (Primadiati, 2002).

Bau yang mengandung ion minyak atsiri yaitu lavender berbahan aktif linalool tersebut dibawa neuron menuju sistem limbik untuk diteruskan ke hipotalamus. Di hipotalamus bau tersebut akan merangsang kelenjar pituitary untuk melepaskan agen kimia kedalam sirkulasi darah untuk mengatur kelenjar adrenal dan tiroid supaya menurunkan aktifitasnya yang sebelumnya dirangsang oleh adanya stimulus stressor yang menimbulkan reaksi hormon epineprin dan norepineprin. Bau ini juga merangsang daerah di otak yang disebut raphe nucleus untuk mengeluarkan sekresi serotonin yang menimbulkan efek rileks sebagai akibat inhibisi eksitasi sel (Carpenito, 2002).

Masase adalah tindakan penekanan oleh tangan pada jaringan lunak, biasanya otot tendon atau ligamen, tanpa menyebabkan pergeseran atau perbahan posisi sendi guna menurunkan nyeri, menghasilkan relaksasi, dan atau meningkatkan sirkulasi. Ada dua teknik masase dalam persalinan, yaitu effleurage dan counterpressure. Pijat counterpressure adalah pijatan yang dilakukan dengan menggunakan tinju atau pangkal telapak tangan pada daerah punggung atau sacrum yang dirasakan paling nyeri. Sedangkan effleurage adalah pijatan ringan yang dapat meningkatkan relaksasi dan menghilangkan nyeri (Danuatmaja, 2008).

Pada ibu bersalin yang diberikan pijat aromaterapi lavender mengatakan bahwa merasa lebih tenang, nyaman dan tidak cemas dalam menghadapi persalinan. Pemijatan yang diberikan memberi manfaat pada ibu bersalin yaitu melancarkan peredaran darah dan meregangkan daerah otot-otot sehingga nyeri yang dialami selama proses persalinan juga semakin berkurang. Selain itu, kandungan dari minyak lavender sangat berguna untuk meredakan nyeri saat kontraksi persalinan.

Penelitian ini sejalan dengan penelitian yang dilakukan oleh Argi dan Susi (2013) yang menyatakan bahwa aromaterapi lavender berpengaruh dalam penurunan intensitas nyeri pada pasien pasca operasi bedah mayor yaitu rerata intensitas nyeri sebelum pemberian aromaterapi lavender adalah 4,80 dengan standar deviasi 2,530 dan intensitas nyeri sesudah pemberian aromaterapi lavender 4,10 dengan standar deviasi 2,807.

3. Pengaruh Pijat Aromaterapi Lavender (Lavandula angustifolia) Terhadap Tingkat Nyeri Persalinan Kala I Fase Aktif

Dari hasil analisis diatas dapat diketahui bahwa nilai t hitung (11.000) > nilai t tabel (2.262) dan nilai $\mathrm{P} 0,000<\alpha$ $(0,05)$ sehingga diperoleh hasil ada pengaruh pijat aromaterapi lavender terhadap tingkat nyeri persalinan kala I fase aktif sebelum dan sesudah pemberian pijat aromaterapi lavender.

Didukung pada tabel 1.6 bahwa ratarata tingkat nyeri pada ibu bersalin primigravida kala I fase aktif pada kelompok eksperimen mengalami penurunan sedangkan pada kelompok kontrol mengalami kenaikan. Pada kelompok kontrol, rata-rata nyeri yang dirasakan pada ibu bersalin yaitu 4,60 menjadi 5,50. Pada fase dilatasi maksimal, rata-rata nyeri dari 6,10 menjadi 7,20. Sedangkan pada fase deselerasi, rata-rata nyeri dari 7,70 menjadi 8,90.

Rata-rata nyeri yang dirasakan pada ibu bersalin yang diberikan pijat aromaterapi lavender pada fase akselerasi yaitu sebesar 4,40 dan setelah diberikan pijat aromaterapi lavender menjadi 3,10. Pada fase dilatasi maksimal, rata-rata nyeri sebelum diberikan pijat aromaterapi lavender 5,40 dan setelah diberikan pijat aromaterapi lavender menjadi 3,60. Sedangkan pada fase deselerasi, rata-rata nyeri sebelum diberikan pijat aromaterapi 
lavender 7,70 dan setelah diberikan pijat aromaterapi lavender menjadi 5,50.

Pada kelompok eksperimen fase dilatasi maksimal, 5 orang mengalami penurunan nyeri dari nyeri sedang menjadi nyeri ringan dan 5 orang mengalami nyeri tetap yaitu nyeri sedang. Sedangkan pada kelompok eksperimen fase deselerasi, 8 orang responden mengalami penurunan nyeri yaitu nyeri sangat hebat menjadi nyeri sedang dan 2 orang responden mengalami nyeri tetap yaitu 1 orang nyeri sedang dan 1 orang nyeri sangat hebat.

Penurunan nyeri terjadi karena pemberian pijat aromaterapi efektif digunakan untuk mengurangi nyeri persalinan sehingga responden merasakan lebih nyaman dan tenang dalam menghadapi proses persalinannya. Sentuhan yang diberikan secara ringan dengan gerakan panjang dan halus memberi pereda terhadap suatu nyeri. Sentuhan ini dapat meningkatkan relaksasi dengan cara memicu perasaan nyaman selama menyentuh permukaan kulit. Jadi ibu yang dipijat selama proses persalinannya akan terbebas dari rasa sakit karena pijat juga merangsang pengeluaran hormon endorphin yang merupakan pereda sakit secara alami.

Pemberian pijat berguna untuk memperlancar peredaran darah, mengatasi kram otot, menurunkan nyeri dan kecemasan, serta mempercepat persalinan. Pijat punggung sangat berguna pada ibu yang mengalami kontraksi yang terus menerus dan nyeri pada daerah punggungnya. Pijatan saat kontraksi dapat memberikan ketenangan dan relaksasi pada ibu (Aprilia, 2010).

Aromaterapi dari lavender bekerja langsung pada sistem limbik untuk mengontrol sirkulasi dan pelepasan serotonin pada raphe nucleus yang berpengaruh pada penurunan aktifitas eksitasi sel keseluruhan terutama di otak dan organ vital (Primadiati, 2002). Serotonin bekerja pada jalur raphe nucleus terutama pada bagian hipotalamus, dan sistem limbik terutama bagian amigdala. Dimana diketahui hipotalamus berfungsi mengatur emosi dasar (basic behaviour paterns), sedangkan amigdala adalah bagian dari sistem limbik yang mengontrol perasaan subyektif yang merangkum emosi, mood, kemarahan, ketakutan dan kegembiraan (Wong, 2010).

Sebuah penelitian pada ibu yang dipijat selama 20 menit setiap jam selama proses persalinan akan lebih terbebas dari rasa sakit. Hal itu terjadi karena pijat merangsang hormon endorphin yang merupakan pereda sakit alami dan dapat menciptakan perasaan yang nyaman (Danuatmaja, 2004).

Aromaterapi lavender bermanfaat memberikan ketenangan, relaksasi, kecemasan, rasa nyaman dan mengurangi stres (sedatif), antispasmodik, analgesik, antiseptik, serta mengobati berbagai gangguan kulit. Pada pasien setelah diberikan pijatan aromaterapi lavender, menunjukkan terjadinya penurunan kecemasan dan penurunan tingkat nyeri.

Menurut penelitian yang dilakukan Abbaspoor dan Mohammadkhani (2012) tentang pengaruh pijat aromaterapi lavender terhadap tingkat nyeri persalinan dan mengurangi lama persalinan dapat diketahui bahwa rata-rata tingkat nyeri sebelum diberikan perlakuan yaitu sebesar 4,56 dan setelah diberikan perlakuan menjadi 3,2. Hal ini berbeda dengan kelompok yang hanya diberikan pijat saja tanpa adanya aromaterapi lavender, yaitu sebelum diberikan perlakuan, rata-rata tingkat nyeri yang dirasakan yaitu 4,6 dan setelah diberikan pijat saja menjadi 4,2.

Penelitian lain yang telah dilakukan oleh Angger Anugerah (2011) tentang pengaruh pemberian aromaterapi lavender terhadap tingkat kecemasan pasien pra operasi juga mengalami perubahan yang signifikan. Pada penelitian tersebut didapatkan hasil bahwa responden dengan kecemasan sedang sebelum diberikan aromaterapi berjumlah 14 responden kemudian diberikan aromaterapi lavender 
berkurang jumlahnya mejadi 2 responden. Sedangkan responden dengan kecemasan ringan sebelum diberikan aromaterapi lavender berjumlah 17 berkurang menjadi 14 responden.

Responden yang tidak mengalami penurunan nyeri terjadi karena responden kurang bisa mengontrol faktor faktor yang dapat mempengaruhi nyeri seperti faktor emosi, sehingga responden kurang bisa mengelola dirinya terhadap suatu nyeri yang mengakibatkan nyeri yang dirasakan tidak mengalami penurunan meskipun sudah diberikan metode pengurangan nyeri.

Hal ini sesuai dengan teori Judha (2012) bahwa faktor emosi (cemas dan takut) ternyata secara fisiologis dapat menyebabkan kontraksi uterus semakin tinggi karena pada kondisi tersebut, tubuh akan melakukan reaksi defensif sehingga dari keadaan stress tersebut merangsang tubuh mengeluarkan hormon stressor yaitu katekolamin dan adrenalin. Akibatnya uterus semakin tegang dan rasa nyeri tak terelakkan.

Sedangkan pada kelompok kontrol fase akselerasi ditemukan 3 orang mengalami kenaikan tingkat nyeri dari nyeri ringan menjadi nyeri sedang yang berjumlah 1 orang, dan 2 orang dari nyeri sedang menjadi nyeri sangat hebat sedangkan 7 orang lainnya mengalami nyeri tetap yaitu nyeri sedang. Pada fase dilatasi maksimal, 5 orang mengalami peningkatan nyeri dari nyeri sedang menjadi nyeri sangat hebat dan 5 orang lainnya tidak mengalami peningkatan nyeri yaitu 2 orang mengalami nyeri sedang dan 3 orang mengalami nyeri sangat hebat.

Pada fase deselerasi, 9 responden berada pada tingkat nyeri sangat hebat dan ada 1 orang yang mengalami peningkatan tingkat nyeri dari nyeri sangat hebat menjadi nyeri terhebat.

Peningkatan nyeri disebabkan karena tidak adanya pemberian pijat aromaterapi lavender, sehingga responden memakai teknik sendiri dalam mengelola nyeri yang dirasakan seperti memakai teknik relaksasi nafas dalam. Jadi metode pengurangan nyeri yang dilakukan sendiri digunakan untuk mengelola nyeri yang sedang dirasakan. Tetapi karena responden belum memiliki pengalaman dalam melahirkan sebelumnya, metode yang digunakan untuk mengurangi nyeri kurang efektif, sehingga nyeri yang dirasakan semakin tinggi seiring dengan penambahan kekuatan kontraksi uterus dan pembukaan serviks.

Semakin besar pembukaan serviks, tingkat nyeri yang dirasakan juga semakin tinggi. Terbukti bahwa rata-rata tingkat nyeri pada fase dilatasi maksimal lebih besar daripada fase akselerasi dan juga lebih besar lagi pada fase deselerasi. Hal ini terjadi pada kedua kelompok baik kelompok yang diberikan pijat aromaterapi lavender maupun pada kelompok yang tidak diberikan pijat aromaterapi lavender.

Seperti teori yang dikemukakan oleh Yudha (2009) yang mengatakan bahwa kontraksi uterus menyebabkan timbulnya nyeri yang memengaruhi mekanisme sistem tubuh seperti proses metabolisme, ventilasi, sirkulasi serta aktivitas uterus. Selain itu, adanya faktor-faktor lain yang menyebabkan terjadinya nyeri persalinan yaitu pasokan oksigen ke otot rahim yang berkurang sehingga menyebabkan otot rahim belum sepenuhnya pulih saat adanya kontraksi uterus yang singkat.

Tidak dapat dipungkiri bahwa ibu bersalin tetap merasakan nyeri meskipun sudah diberikan metode nonfarmakologis seperti pijat aromaterapi lavender sebagai salah satu metode pengurangan rasa nyeri. Nyeri yang dirasakan pada ibu bersalin yang diberikan metode nonfarmakologis akan lebih rendah bila dibandingkan nyeri yang dirasakan pada ibu bersalin tanpa pemberian metode nonfarmakologis.

\section{SIMPULAN DAN SARAN}

Simpulan penelitian adalah: 1). Lebih dari setengah responden yang tidak diberikan pijat aromaterapi lavender 
mengalami nyeri sangat hebat 2) Lebih dari setengah responden yang diberikan pijat aromaterapi lavender mengalami nyeri sedang 3) Ada pengaruh pijat aromaterapi lavender (Lavandula angustifolia) terhadap tingkat nyeri persalinan kala I fase aktif di BPM Wilayah Kerja Puskesmas Blabak Kabupaten Kediri.

Saran yang diajukan adalah: 1). Diharapkan dapat mengaplikasikan metode ini sebagai salah satu metode nonfarmakologis untuk menurunkan tingkat nyeri selama proses persalinan 2) Menambah sumber referensi sehingga dapat memberikan manfaat kepada pembaca khususnya tentang pengaruh pijat aromaterapi lavender terhadap tingkat nyeri persalinan kala I fase aktif 3). Penelitian ini dapat dikembangkan pada penelitian selanjutnya dengan menggunakan metode lain dalam pemberian aromaterapi seperti menghirup, mengompres, pengolesan di kulit ataupun berendam. Serta metode-metode nonfarmakologis lain yang berhubungan dengan tingkat nyeri persalinan seperti metode hidroterapi, yoga ataupun metodemetode nonfarmakologis yang lain.

\section{DAFTAR PUSTAKA}

Amru, S. 2012. Rustam Mochtar Sinopsis Obstetri Jilid I. Jakarta: EGC.

Anugerah, A. 2011. Pengaruh Pemberian Aromaterapi Lavender Terhadap Tingkat Kecemasan Pasien Pra Operasi di Rumah Sakit dr Soebandi Jember. Program Studi Ilmu Keperawatan Universitas Jember.

Aprilia,Y. 2010. Hipnostetri: Rileks, Nyaman dan Aman Saat Hamil dan Melahirkan. Jakarta: Gagas Media.

Arikunto, S. 2006. Prosedur Penelitian Suatu Pendekatan Praktik. Jakarta: Rineka Cipta.

Argasetya, S.M. 2007. Mengatasi MualMual Selama Kehamilan dan Gangguan Lain Selama Kehamilan. Diglossia: Yogyakarta.
Asmadi. 2008. Teknik Prosedural Keperawatan: Konsep dan Aplikasi Kebutuhan

Dasar. Jakarta: Salemba Medika.

Balkam, J. 2001. Aromaterapi Penuntun Praktis untuk Pijat Minyak Asiri dan Aroma. Semarang: Dahara Prize.

Bakir, R.S. 2009. Aroma Terapi. Tangerang: Karisma.

Bangun, A.V. dan Susi Nuraeni. 2013. Pengaruh Aromaterapi Lavender Terhadap Intensitas Nyeri Pada Pasien Pasca Operasi di Rumah Sakit Dustira Cimahi. Program Studi Keperawatan Sekolah Tinggi Ilmu Kesehatan. Jenderal Achmad Yani Cimahi.

Carpenito, L.J., 2000. Diagnosa Keperawatan Aplikasi pada Praktik Klinis edisi 6. Jakarta: EGC

Danuatmaja, B dan Mila Meilisari. 2008. Persalinan Normal Tanpa Rasa Sakit. Jakarta: Puspa Swara.

Dinas Kesehatan Jawa Timur. 2013. Profil Kesehatan Jawa Timur Tahun 2012. Surabaya.

Dinas Kesehatan Kabupaten Kediri. 2013. Laporan PWS KIA Dinas Kesehatan Kabupaten Kediri tahun 2013.

Ester, M. 2008. Buku Ajar Kebidanan Komunitas. Jakarta: EGC.

Fraser, Diane., Cooper, Margaret. 2011. Buku Ajar Kebidanan Myles. Jakarta: EGC.

Hakimi, M. 2010. Ilmu Kebidanan Patologi dan Fisiologi Persalinan.Yogyakarta: Yayasan Essentia Medica.

Hidayat, A. A. A. 2007. Metode Penelitian Kebidanan dan Teknik Analisis Data. Jakarta: Salemba Medika.

Dasar Praktik Klinik
untukKebidanan. Jakarta: Salemba Medika.

JNPK-KR. 2007. Asuhan Persalinan Normal. Jakarta: Depkes RI. 
Judha, M. 2012. Teori Pengukuran Nyeri dan Nyeri Persalinan. Yogjakarta: Nuha Medika

Jumarani, L. 2009. The Essence Indonesian Spa: Spa Indonesia Gaya Jawa dan Bali. Jakarta: Gramedia Pustaka Utama.

John, W. 2007. Terapi Pijat Memijat Diri Sendiri Guna Memperoleh Kesehatan Fisik dan Psikis. Jakarta: Prestasi Pustakarya.

Kartikawati, N. 2010. Buku Ajar DasarDasar Keperawatan. Jakarta: Salemba Medika.

Koensoemardiyah. 2009. A to Z Minyak Atsiri untuk Industri Makanan Kosmetik dan Aromaterapi. Jakarta: Andi.

Manuaba, I.G.B. 2010. Ilmu Kebidanan, Kandungan dan KB. Jakarta: EGC.

Maryunani, A. 2010. Biologi Reproduksi dalam Kebidanan. Jakarta: TIM.

Notoatmodjo, S. 2010. Metodologi Penelitian Kesehatan. Jakarta: Rineka Cipta.

Nursalam. 2008. Konsep Dan Penerapan Metodologi Penelitian Ilmu Keperawatan Pedoman Skripsi Tesis dan Insrumen Penelitian Keperawatan. Jakarta: Salemba Medika.

Permenkes RI. 2004. Pedoman Persyaratan Kesehatan Pelayanan Sehat Pakai Air (SPA ). Jakarta.

Praptiani, W. 2012. Kebidanan Oxford dari Bidan untuk Bidan. Jakarta: EGC.

Primadiati, R. 2002. Aromaterapi Perawatan Alami Untuk Sehat \& Cantik. Jakarta: PT Gramedia Pustaka Utama.

Rahayu, D.Y. dan Esty Wahyuningsih. 2010. Kegawatan dalam Kehamilan Persalinan. Jakarta: EGC

Satyanegara, S. 2008. Panduan Lengkap Kehamilan, Melahirkan, dan Bayi. Jakarta: Arcan.

Subekti, N.B. 2004. Nyeri Persalinan. Jakarta: EGC.
Sugiyono. 2012. Statistika untuk Penelitian. Alfabeta: Bandung. 2013. Metode Penelitian Pendidikan (Pendekatan Kuantitatif, Kualitatif dan $R \& D)$. Alfabeta: Bandung.

Sulistyowati, D. I. D. 2012. Efektifitas Terapi Aroma LavenderTerhadap Tingkat Nyeri dan Kecemasan Persalinan Primipara Kala I Di Rumah Sakit dan Klinik Bersalin Purwokerto. Universitas Indonesia.

Sumarah. 2009. Perawatan Ibu Bersalin (Asuhan Kebidanan pada Ibu Bersalin). Yogyakarta: Fitramaya.

Wahyuningsih, E. 2008. Buku Ajar Asuhan Kebidanan. Jakarta: EGC.

Wijayati, M.A. 2005. Buku Ajar Keperawatan Maternitas. Jakarta: EGC.

Wiknjosastro, S. P. 2007. Ilmu Kebidanan. Jakarta: YBP-SP.

Yudha, E.K dan Nike Budhi. 2009. Obstetri Williams Panduan Ringkas. Jakarta: EGC.

Yuliatun, L. 2008. Penanganan Nyeri Persalinan dengan Metode Nonfarmakologis. Malang: Banyumedia Publishing.

Zahra, A. Dan Leila, M.S. 2013. Lavender Aromatherapy Massages in Reducing Labor Pain and Duration of Labor. African Journal of Pharmacy and Pharmacology. Halaman 426-430. 